\title{
A Study of Financial Risks of Listed Manufacturing Companies in China
}

\author{
Fang Fang \\ Accounting School, JiangXi University of Finance and Economics, Nanchang, China \\ Email: Fiona0910@yeah.net
}

How to cite this paper: Fang, F. (2016). A Study of Financial Risks of Listed Manufacturing Companies in China. Journal of Financial Risk Management, 5, 229-245. http://dx.doi.org/10.4236/jfrm.2016.54022

Received: September 26, 2016 Accepted: November 28, 2016

Published: December 1, 2016

Copyright $\odot 2016$ by author and Scientific Research Publishing Inc. This work is licensed under the Creative Commons Attribution International License (CC BY 4.0). http://creativecommons.org/licenses/by/4.0/ (c) (i) Open Access

\begin{abstract}
Financial risk is an objective phenomenon in economic activities. It has received extensive attention in theoretical and practical fields. For each company and operators in the market economy, the financial risk is an objective existence. The manufacturing industry as a pillar industry of China's economic development, occupies a large proportion in China's listed company. However because of the characteristics of its own manufacturing and the increasingly fierce market competition, some manufacturing listed companies went to bankruptcy because of financial risk crisis, so the research on manufacturing listed company financial risk has a very far-reaching significance. With the development of society, the financial risk is becoming more and more complex. This theory will combine research results and empirical analysis, define the concept of financial risk in manufacturing enterprises, use listed Chinese manufacturing companies as the research object, to analyze the cause of financial risk on the basis of reasoning analysis. This article aims to put forward measures to deal with financial risks, according to the Chinese manufacturing industry development situation, using both internal price control mechanism construction and financial risk management mechanism to protect the interests of stakeholders.
\end{abstract}

\section{Keywords}

Manufacturing Industry, Financial Risk, Risk Control

\section{Introduction}

\subsection{Research Background and Significance}

With the development of economic globalization, enterprises are facing double competition and challenges from home and abroad. Therefore, in order to remain invincible, enterprises must be able to quickly adapt to the change of the economic environment at home and abroad, in order to expand the operation scale, increase market share, and 
realize the enterprise value maximization. In the financial activities of the process, the financial risk is inevitable. Therefore, having an in-depth understanding of the origin of financial risks, and taking effective measures to eliminate financial risk when it's still controllable are of great necessity. Taking listed manufacturing companies as an example, this article aims to analyze generated causes and figure out countermeasures of financial risk.

The scale and level of manufacturing industry are important symbols to measure a country's comprehensive strength and the degree of modernization. Although the world is entering the information age, but the contemporary most economically developed countries are still the most developed countries in manufacturing industry. Since the reform and opening up, our booming manufacturing industry has become a major force that drives the economic development of the whole nation. In addition, the global trade has become more and more common, as the share of exports accounted for a large proportion in the whole international trade. The production of some industry even exceeded many developed countries and became the biggest in the world, such as electronics, textiles and so on. The reform of the entire industry has become increasingly international. It went through the transition from labor-intensive to technology intensive. Many business entities have increased their investment in Chinese manufacturing market, and improved the manufacturing level of hardware and software.

At present, China is a big manufacturing country, but not a manufacturing powerhouse. Chinese manufacturing industry has developed rapidly, but the competitive advantage is not obvious; the innovation ability is poor; the gap between science and technology and economic development can't be neglected; the proportion of foreign capital is too high; most importantly, it is still characterized as a rapid developer of labor intensive industry. In addition, with the development of the international economy continues accelerating and the spread of the global financial crisis, the manufacturing industry is still facing increasingly complicated economic environment, increasing competition and the accumulation of enterprise's financial risk, which ultimately lead to the financial crisis. In equity market in Shanghai and Shenzhen, manufacturing listed corporation got ST (special treatment) due to financial problems accounted for a high proportion of all listed corporations. China has 868 manufacturing industry listing corporations, of which the financial crisis occurred in as many as 300 companies; many star enterprises went bankrupt; the reasons of collapse are very similar: mostly because of neglect of effective prevention of financial risks which leads to the deterioration of the financial situation of the enterprise and even the facture of cash flow.

As the manufacturing industry booming and strategic position improving, by analyzing the causes and coping strategies of financial risk of manufacturing listed Corporation, it has great practical significance for management, investors, creditors and other stakeholders. Management is able to identify financial risks according to certain kinds of evaluation index, discover the causes of the deterioration of the financial situation of the company timely, and adjust business strategy accordingly, reverse the malignant situation to enhance their ability to resist risks and avoid embarrassing situation like 
insolvency, poor sales of inventories, high cost and invalid decision etc. Since the financial risk is objective and inevitable, it's especially important for listed Corporation to find a balance between investment returns and risks since risks and benefits is a game, high-yield means high risks.

\subsection{Research Achievements at Home and Abroad}

Financial risk is a kind of financial activities that during the production process, due to a variety of risk factors, the uncertainty of capital and the motion of cash flow, may eventually lead to the result that company's future financial income is different from people's expectation. Zhang ZuMin (2010) believes that the concept of financial risk of rain and generalized the points, narrow financial risk refers to the risk of enterprise using financial leverage caused in the financing process, we can also be referred to as the generalized financing risk. The financial risk means that during financial activities, the company's financial income and expected return would have deviation due to internal and external environment and the influence of various uncertain factors, and lead to the possibility and opportunity to loss.

Western classical economists has proposed the concept of risk in the 19th century, that risk is by-product of the business activities, income of the manager of the risks in the business activities of reward. In a narrow sense of the word, the financial risk of the enterprise is that due to the large changes in the magnitude of the risk of using debt brings to the enterprise bankruptcy risk or common stock returns. This view based on enterprise financing too much debt or debt improper. Western countries emphasize the idea of comprehensive risk management is from the fund movement to capital operating process of the system as a whole, the financial risk control including the risk early warning, risk identification, crisis management content.

Published in the 1921, <Risk, Uncertainty and Profit> written by American economist Frank H. Knight (1921) proposed that risk refers to the "measurement uncertainty" and "uncertainty" is that the risk is not to be measured. Feature of the risk is the probability estimation of reliability, probability estimation of reliability from the theoretical rules followed or stability of the experience rule. And can be calculated or foreseeable risk of different, uncertainty just people lack the basic knowledge of the event, possibly for the event as a result of poorly understood, therefore, we cannot conduct predictive and quantitative analysis through the existing theoretical and experiences.

Ross, Westerfield and Jordan (1995) mentioned in < Fundamentals of Corporate Finance $>$ that debt financing will increase the risk of shareholders, and the additional risks are called the financial risks of the shareholders of the company. That is to say, the financial risk is due to the company's financial policy of the equity risk.

American scholar C. Arthur Willianms and Richard M. Heins (1985) defined risk in $<$ Risk Management and Will Be Insurance $>$ as in a given situation and specific time, differences between those results may occur. If the affirmative results in only one, the difference is zero, zero risk; if there are a variety of possible outcomes, risk, and the greater the difference, the greater the risk. This kind of view stressed that the risk is the 
objective existence of things can from an objective point of view to measure.

Overall, foreign financial risk research started early, it has a complete theoretical system and application widely and research results and system. For example, foreign risk management association, the school of risk management of enterprise risks management affairs, professional certificate examination system very with. Among them, the global association of risk professionals every year held financial risk management personnel professional certificate examination, many associations and societies published risk management journals, has published a lot of books about financial risk management.

As for domestic view about the definition of financial risk, a popular view is that company's financial risk refers to the risk in the financial activities, due to the influence of a variety of difficult to predict or control factors, the financial situation with uncertainty, so that enterprises receive damage to the possibility of failure. He divided financial risks into four parts, namely, investment risk, cash flow risk and foreign exchange risk.

Although the above viewpoint has different classification of financial risk, but all suggested that financial risks of enterprise was due to a variety of uncertain factors in financial activities which caused the gap between financial income and the expected return, resulting in the loss of opportunity and possibility. The organization and management process of enterprise financial activities in one hand and a part of the problem may cause the risk into losses, resulting in the decrease of corporate profitability and solvency. According to our country's scholars' point of view, it is not difficult to conclude that the causes of financial risks of enterprise are closely related to the impact of external and internal environmental factors. As a result, this paper will also analyze the reason of financial risk on the basis of internal and external environment of listed Corporation.

Li Ji (2010) published an article called: "Research about the early warning indicators of listed company financial crisis". The author believes that so far abroad has developed several financial crisis evaluation model, some model in credit risk assessment and management of enterprise credit evaluation practice has been widely used. And in China on the financial crisis early warning indicators still use the traditional way of experience, therefore, to explore our country enterprise financial crisis early warning index system of deepening the economic system reform of our country has a strong theoretical significance and more urgent practical significance.

Kong Yuanying (2010), published "on the enterprise financial risk control suggestions" that the enterprise financial crisis is a gradually emerging, slow deterioration process, it has a certain aura. Therefore, it has the predictability. In order to avoid and guard against financial risks, companies need to full understanding and analysis of the financial risk, timely corrective, improvement, and formulate the corresponding countermeasure, effectively improve the financial risk early warning mechanism.

\subsection{Research Methods}

Combining with accounting, risk management, financial management, and other sub- 
jects of theoretical knowledge, the theoretical analysis and case analysis combined method, make full use of the network and library resources, to our country individual manufacturing industry listed company financial risk are compared. Theoretical research to through the study and analysis of the domestic and foreign financial risk control literature, it summed up the status quo of the relevant research of the financial risk control, to build a financial risk analysis theory. There are some cases from Chinese manufacturing listed company, selected assessment methods for financial risk. At the same time, those cases were analyzed and compared.

\section{An Overview of Financial Risk}

\subsection{The Concept of Risk}

Risk is a natural phenomenon in social economic environment. Once the risk is changing, it will result in a certain state and within a certain period of time. Usually, the risk comes up with two or more results, due to the uncertainty of future.

\subsection{The Concept of Financial Risk}

The financial risk is one of the most common risk, mainly refers to the enterprise in daily business activities due to various factors and control of enterprises caused by There's no telling, the actual financial income and the expected bias uncertainty. Financial risk is divided into two broad and narrow sense, a financial risk is often called debt risk or financing risk, is refers to the enterprise caused by debt financial uncertainty. Because the yield of enterprise management and the loan interest rate uncertainty, there may be enterprise's profit rate is higher or lower than the loan interest rate, the magnitude of this risk and the debt scale, scale is larger, the greater the risk is. Once there is heavy debt, enterprise do not have the ability of repayment, it may lead to the enterprise financial risk or bankruptcy. The generalized financial risk is the risk of the enterprise from the view of the whole process of the enterprise management. Under the condition of market economy, enterprises Industry between the increasingly fierce competitions, managers are only in charge of the enterprise's financial activities of comprehensive system management and monitoring, jump out of the box in enterprise financial operation risk analysis, in order to realize the effective management of the enterprise. In this paper, we mainly discuss the generalized financial risk.

\subsection{Types and Characteristics of Financial Risk of Manufacturing Listed Company}

General financial risk is divided into four categories, namely, financing risk, investment risk, capital recovery risk and income distribution risk.

The financing risk is refers to the enterprise operating liabilities to the financial results of uncertainty. The risk of financing business mainly from several aspects, the first is the unreasonable capital structure. The capital structure refers to the enterprise long-term debt and equity capital ratio, and it is closely related to the success or failure of the enterprise. The second is the debt maturity arrangements are not reasonable. If 
the short-term debt ratio the structure is not reasonable, repayment period is too concentrated, that will cause the enterprise in the repayment of debt maturity when the pressure is too large, resulting difficulty in capital turnover financial risk despite the change of exchange rate. If the enterprises borrowed in foreign currency, it may have to exchange risk because of the exchange rate change, if access to the foreign currency borrowing again during appreciation because of the increase of enterprise, due for repayment of principal and interest costs may be faced with financial risks. Finally, the change of interest rate, exchange rate changes and causes similar. If the money supply reduces, which led to the increase in loan interest rates, the company will increase the risk of financing because of increased funding costs.

Investment risk refers to the enterprise to invest some money, because of changes in market demand and the influence of the ultimate risk income and the expected return. Foreign investment enterprises are mainly direct investment and portfolio investment in two forms. In China, according to the provisions of the company law, more than $25 \%$ shareholders owned shares should be regarded as direct investment. Securities investment commonly has two forms which are stock investment and bonds investment. The stock investment is risk sharing, benefit sharing forms of investment; bond investment has no direct relationship with the invested enterprise financial activities, just receive regular fixed rate of interest, investors who are facing the risk are unable to repay their debts. Investment risks include interest rate risk, investment risk, the exchange rate risk, inflation risk, financial derivatives risk, moral risk, the risk of default.

Whether the enterprise product sales, the two transformation process depends on the capital. That is a process of transformation from product capital settlement funds. While the other is a process from the settlement funds for the money. Time and amount of capital recovery risk is two conversion process of uncertainty. At present Chinese manufacturing industry listed Company liquidity is relatively large and many were overstocked inventory backlog of inventory. Poor liquidity takes up the company a lot of money on the one hand. On the other hand the company must keep the stock to pay a lot of care costs, leading to increased costs, reduced profits. The long-term stock market prices bear the inventory loss and damage caused by unsuitable storage, which will result in financial risk.

Distribution of income risk is due to changes in tax rates or income distribution unreasonable, for production and business activities of enterprises to bring the possibility of adverse effects. Due to the improper selection of changes in the objective environment and accounting methods, it is possible to lead to enterprise less cost, multi confirmation current income, thus causing false profit of the current period, makes the enterprise in advance tax, because a lot of money in advance out of the trigger financial risks. So if managers cannot come up with income allocation of time, distribution amount appropriately, it will cause a shortage of funds which is also financial risk.

All of the financial risk impact on enterprise is concentrated in the enterprise's financial position and operating results. So the financial risk of the enterprise has many characteristics: 
Objectivity. The financial risk of the enterprise is a kind of inevitable phenomenon, which changes with the objective environment and condition. This characteristic of the financial risk can help people take the initiative to explain because of the objective reasons of the financial risk and the financial risk could be identified.

Uncertainty. The financial risk is potential. It is uncertainty, which is the financial risk of enterprise produces necessary conditions. If there is no uncertainty, then there is no risk, for it is helpful to the control of financial risk.

Measurable. The financial risk is an objective existence, so it can be used mathematical methods such as probability and statistics to measure. If the financial risks of enterprise can't be measured, the control of the financial risk is only a talk.

Complexity. The cause of the financial risk, manifestation and influence and the action are all complex. The cause of the financial risk is a complex, which may come from operators of their own reasons or external reasons. Some of them can be predicted, while others cannot be predicted. Therefore, the operator must take a variety of measures to deal with different situations. In addition, the process of the formation of financial risk is a complex, because it's difficult to carry on a comprehensive master.

\subsection{Financial Risk and Economic Benefit of Manufacturing Listed Company}

Markowitz (1952) put forwarded in the <portfolio selection $>$ that there are certain special relationship between the financial assets of the risk investment and economic benefits, the dispersion of investment risks with a certain regularity. His theory has four assumptions:

1) The market is effective, and investors can live all the information on investment and earnings risk changes.

2) Investors choose the appropriate portfolio according to the expected return of the investment assets and the standard deviation. The investment portfolio usually has a higher income or lower risk.

3) Investors who are averse to risk hope to obtain a higher return and lower risk, the risk is measured by the statistical variance.

4) There are some relationships between variety of financial assets, as long as the relevant coefficient is appropriate, you can choose a lower risk of higher income portfolio.

According to the above four hypotheses, Markowitz assess the risk of the portfolio of $\mathrm{N}$ pieces on investment asset by using the "pre return variance analysis" measure. The formula is as follows:

$$
\sigma_{p}^{2}=\sum_{i=1}^{n} W_{i}^{2} \sigma_{i}^{2}+\sum_{i=1}^{n} \sum_{j=1}^{n} W_{i} W_{j} \sigma_{i j}
$$

In the equilibrium, $n$ represent the numbers of kinds in the portfolio, represent the proportion that the $i^{\text {th }}$ asset counts in the portfolio, means the covariance of the expected return of the $i^{\text {th }}$ asset and the $f^{\text {th }}$ asset.

The traditional investment theory is generally believed that there is a higher risk of asset size, income is uncertain. And now the portfolio theory is that the decisive factor of risk assets is not only the risk of one-way independent assets, but the risk assets of 
the whole portfolio of enterprises. To make investment decisions, to measure the risk of income, should starting from the best angle of assets, not only consider an asset portfolio, because the correlation coefficient between them, if not strong correlation can spread the risk. In this "expected return variance analysis formula", when the number of assets in the portfolio increases, the variance of single asset portfolio of the overall effect is more and more small, affect the covariance between the portfolios will be bigger. In the combination of assets, range to achieve certain number, single asset variance of portfolio overall variance almost had no effect, or has a negligible effect on investment portfolios. Investors are risk averse. They can satisfy their appetite for risk through combination of the risk-free asset and risk assets. Investment portfolio therefore will strive to achieve revenue maximizing the same risk degree, or equivalent income risk minimization.

Under normal circumstances, the rate of change is not directly related, but the direction of change is roughly the same. Once there are some of the reverse changes, the risk of investment portfolio is the dispersion and will be offset. But types continue to increase at the same time, counteract the risk degree also continued to reduce, finally only non-diversifiable risk is caused by market factors. Enterprise managers must reasonable allocation of the portfolio to diversify risk, to look for highest gains under the condition of certain risks or to look for the lowest risk. Finally to meet the object of expected investment income maximization principle.

\section{Financial Risk Analysis of Manufacturing Listed Company}

\subsection{Manifestations of Financial Risk in Manufacturing Listed Company}

There are various forms of financial risk, and there are five typical forms of financial risk in manufacturing listed company.

1) Low profitability, poor economic efficiency.

Its specific performance includes high product cost, low gross margin; poor asset income levels, low rate of return on investment. In the long term, the profitability is the ability of generating cash, which is most reliable measurement for manufacturing performance of listed companies. In fact, the cash source that company repay the debt comes from investment after the cash inflows, if that cash inflow cannot is greater than or equal to the cash outflow, weakness of repaying debts that are due. It means high financial risk.

2) Lack of funds, lack of solvency.

Specific performance is low funds, excessive debt; low level of credit, financing ability is poor. If the company hold moderate debt rate, they can have the access to financial leverage interests. But excessive debt can lead to corporate credit rate decreasing. On the other hand, it will weaken the company's ability to pay, once the credit chain on a part of the problem, or the actual net cash flow less than expected, it will affect the debt that due to pay, even financial crisis.

3) The debt structure is unreasonable.

Generally speaking, short-term debt funds of enterprises should be used for current 
assets. The more accurately saying is that should be used with the consistent of quick assets. When the enterprise did not have enough cash to repay maturing debt, the method is to transform current assets to quick assets to repay debt. If short-term corporate debt provided ratio is too high, or the short-term borrowing funds to invest in liquidation of fixed assets and other long-term assets, it will reduce the liquidity of the assets of an enterprise, the impact of short-term debt paying ability.

4) Poor operating capacities, high proportion of non-performing assets.

Specific performance is high level of poor quality of assets, settling down a large number of bad debts and defective unsold inventory, asset turnover is low. Assets are owned or controlled by enterprises, which can be expected to generate economic benefits of resources. Its turnover rate reflects the efficiency of the application of assets in enterprises. Enterprise assets management ability is poor, not only related to the ability to reach the expected goal, but also influence the future development of the enterprise and the possibility of financial crisis in future.

5) Growth ability is weak, enterprise development is stagnant.

Specific performance is the declining of capital accumulation rate of enterprise and sales growth rate and the shrinking of market share. Growth ability reflects the trends in the development of enterprises. Temporary growth down perhaps does not mean the advent of the financial crisis of the enterprise, but long-term growth decline, usually means that enterprises is entering the recession, or a problem with the business are embodiment of enterprise financial risk which is compounded.

\subsection{Analysis on the Causes of Financial Risk of Manufacturing Listed Company}

There are many reasons to cause the financial crisis of listed companies, including not only the internal management aspects of company, but also macro aspects, such as the government's macro-control measures, changes in the business environment which express the manufacturing industry financial situation.

The first is the external reason. The macro environment of manufacturing listed company is complex, external causes of this is the company's financial risk. The macro environment includes economic environment, legal environment, market environment, social and cultural environment, natural environment and other factors. These factors exist in the enterprise do have a significant impact on the financial management of enterprises. It is difficult to accurately foresee and cannot change the macro environment. Therefore, adverse changes in the macroeconomic environment will bring financial risk to the enterprise. For example, the world oil price rise in oil prices, which makes some manufacturing enterprises in the process of transport increasing operating costs, reducing profits. Therefore it is difficult to achieve the expected return, so financial management system of the company must have the ability to adapt to the complex external environment, otherwise it will be easy to face the financial risk. But in fact, that ability of Chinese manufacturing listed company are lack. Up to 2014 August, China's entire manufacturing export value accounted for the proportion of sales revenue, which 
reached 19.15\%. That high level means Chinese has been well integrated into the world economy in such an environment, the foreign market demand has become one of the important driving forces of China's domestic economic growth. China's economy and the world economy have formed a complementary partnership. But unfortunately, the excessive trade dependency and concentrated trade destination reduce the listed manufacturing enterprise's ability to defense risks. At present, in the 30 manufacturing industries, the number of manufacturing industry reached 13 which export dependence is higher than the $20 \%$. For example, the communications equipment, a computer and other electronic equipment manufacturing industry export dependence is as high as $68.64 \%$. Textile and apparel, hats, footwear manufacturing exceeded $40 \%$. Therefore, if there is any fluctuation in the international market, the manufacturing company will face very serious problem of excess production capacity, which will lead to the financial risk of the company, and even intensified fluctuations in the national economy as a whole.

Second is the internal reason. Through the observation of manufacturing listed companies' financial activities the basic content, we can found that the financial risk of the company can be divided into financing risk, investment risk, capital recovery risk allocation of risks and benefits four, this paper has in the a detailed description of the definition of the four kinds of risks, this section mainly analyzes the reason for four kind of different risks.

\section{The reason for financing risk:}

1) Improper external financing decision of enterprises. Whether the enterprise external financing decision is properly will not influence on the enterprise financing risk greatly. The scale of the enterprise financing, financing structure, financing way and time, debt maturity arrangements are factors of financing risk.

2) The division of financing subject is unreasonable. Debt financing and equity financing will involve the problem of who is the subject, if the financing subject is not appropriate, the risk of corporate finance will increase.

3) The internal conflict of interest. Internal financing establish on the basis of the interests of all parties. It's very difficult to give full consideration to the interests of each member, therefore may reduce the efficiency of allocation of funds in the enterprise, and then increase the risk.

4) The internal financing environment is not standardized, the credit policy is not properly taken by enterprises, the financial policy is distorted, resulting in the lack of corporate liquidity, which lead to inability of reinvestment or repay debt and then increase financial risk.

The reason for investment risk:

1) The enterprise external investment risk. Improper selection of external investment enterprises. The poor management will cause operating losses. The external investment enterprise blindly actions will lead to the inability of repaying principal and interest or dividends, which will impact corporate earnings.

2) Internal project investment risks. The risk of internal project investment is mainly 
reflected in the changes in the product needs, changes in prices and costs as well as poor management and other aspects.

\section{The reason for capital recovery risk:}

1) Improper decision of corporate liquidity. Liquidity in the enterprise management decision mainly reflected in cash, accounts receivable and inventory allocation. If the enterprises hold too much money and inventory or credit policy is too loose, or in order to improve sales performance and profit in the book the credit, can make the enterprise loses buying opportunity and risk return or increase the difficulty of the accounts receivable, reduce risk return.

2) The overall development strategy of the enterprise is not implemented properly. If the overall strategy is not implemented properly, the cash inflow and outflow will be controlled at random, and the cash flow structure of the enterprise will be abnormal, resulting in risk.

\section{The reason for income distribution risk:}

1) The property right is not clear, the property right is the basis and the basis of the distribution of profits, the relevant system of our country is not perfect, the property right which is not clear is the enterprise internal conflict of interest, resulting in the risk of profit distribution.

2) Financing capacity is limited. Cost is too high. Enterprise under debt pressure, and liquidity is weak. Enterprises in the construction process, resources have not been fully integrated, profit fluctuations larger, financing capability and cost limits the profit allocation, the allocation of the profit level affect the company's solvency and liquidity. The disrupt of the distribution of profits and the decline in investor confidence will lead to further increasingly financial risk of the enterprise.

\subsection{Current Situation of Financial Risk Management and Control in Manufacturing Listed Company}

At present, many of China's manufacturing enterprises have already set up the financial risk management system, do some financial risk assessment mainly from the aspects of financing risk, investment risk, liquidity risk and interest rate risk enterprise, and then make a decision. The manufacturing industry is a capital intensive industry. During a process of large amount of money, there can produce the corresponding financial risk. although most of the manufacturing listed company has formed a set of financial risk management system, but as for the reasons such as unreasonable organization, low quality of management personnel, evaluation content is not comprehensive, the management of the foundation work is weak and the financial management regulatory system is not perfect, the financial risk management system of enterprise is the lack of adaptability and strain changes of the internal and external environment. Take the listed company electric appliance manufacturing industry as an example, according to a Peking University crisis management Science and research group in October 2009, Shanghai and Shenzhen two city electrical appliance manufacturing enterprises of random telephone interviews, the statistical results show that the $43.2 \%$ of enterprises are 
in general risk status and $13.4 \%$ of enterprises are in high risk. That is, more than half of the electrical appliances manufacturing enterprises in more than moderate financial risk. Many enterprises rely mainly on qualitative analysis method to evaluate the financial risk, unable to do risk assessment for the whole range of enterprise. At the same time, the lack of knowledge and training of internal financial risk will lead to the enterprise financial risk early warning and assessment system run out of use.

\subsection{Problems about Control and Management of Financial Risk Faced by Manufacturing Listed Company}

There are a lot of problems in the process of financial risk assessment of China's manufacturing listed company, mainly in the following aspects:

1) Lack of initiative in financial risk assessment

The existing risk management is almost post control. Some of them are lack of systematic, regular assessment, risk management consciousness. Management are lack of enthusiasm and initiative. Management does not spend too much energy to run system and consider the relationship of its business portfolio risk and the risk. As a result, there are uneven allocation of resource, losing the efficiency and effectiveness of corporate financial risk management. In a word, for lack of the ability of identifying the financial risk, the management are not conducive to fundamentally solute major financial risks and thus losses come up.

2) Serious experience of decision making

The top managers of the enterprises due to the lack of awareness of risk oriented, knowledge of the risk management master insufficient, leading to the experience of making the phenomenon exists generally, policymakers cannot recognize the risks brought by the financial decision-making mistakes, leading to blind investment suffered a major loss. Such as enterprise in the fixed assets investment, due to no prior to the feasibility of investment project and thus may bring the benefits and risks of system, sufficient research, information and for the decision maker's imperfect, decision-makers decision-making ability good buckwheat missing factors, eventually leading to investment decision-making mistakes, financial risks.

3) Flawed enterprise financial risk management system

At present, as for the lack of risk awareness and basic knowledge of risk among the management, there are many decision errors. Because they cannot identify the signal of risks, and then losses come up. There are many imperfect places and the financial budget management system of many enterprises, such as enterprise cost control system is not perfect, the financial internal control system is not mature, the fund management system the failure and the information transmission system is lagging behind, not accurate. In addition, there are some chaos phenomenon between the enterprise and its affiliated enterprises, such as internal departments in charge of the use of funds and income distribution. That will result in inefficient use of funds, affect the safety and integrity of capital. In short, a series of factors will cause the financial risk assessment system cannot play its due effect. 
4) Relatively scarce method to prevent the financial risk of enterprises

Part of the enterprise's financial risk prevention system is not perfect enough. Because most of the financial risk assessment methods tend to seek public financial data, which may ignore the quantification of non-financial indicators, caused by the established model has certain vulnerabilities. In addition, using the same model, selecting different samples may also cause different estimation results. It's difficult to find out a method that can be widely applied to evaluation of all of the financial risks of enterprise, or be always applicable for the risk assessment under varying degrees of restrictions.

\section{Countermeasures of Financial Risk for Manufacturing Listed Company}

Under the environment of the current economic globalization, manufacturing listed companies how to achieve orderly production and operation. When the product sales are booming, it's really challenging for the management of Listed Companies in the manufacturing industry who are doing decision-makings. In this paper, from microscopic point of view, we mainly put forward the following several corresponding financial risk prevention measures, to provide decision-making reference for the management of the manufacturing companies.

\subsection{Improve the Ability to Adapt and Strain}

Correct analysis of the macroeconomic environment and its changes, and then improve the ability of their adaptation in the business changing environment. The only one thing that does not change is change itself. Changes in the macro environment allow the company also to face the challenges and opportunities. In order to guard against financial risk, the manufacturing industry listed companies should do in-depth analysis of the characteristics of their own business, studies about the changing macroeconomic environment, to grasp the change trend and regularity and to develop a variety of contingency measures, to adjust the financial management policy and to change management methods so as to improve the change of financial management environment adaptation ability and the strain capacity. When they meet the challenges, they can seize the opportunity, in order to reduce financial risks caused by environmental changes.

\subsection{All-Involved Risk Management Mechanism}

Establish an all-involved risk management mechanism. The full implementation of the risk management mechanism, is to melt the risk mechanism into the internal financial risk and clear regulatory responsibilities for all members. The company need to implement responsible for the classification system, including managers, employees and enterprises who are need to share the risk responsibility. And then straighten out the internal financial relations, complete the implementation of post responsibility risk management. On that way, the company could make clear division of responsibilities and duties, so risk prevention team could play the role. The establishment of risk decision making operators incentive and constraint systems. It is used to improve the incentive 
system as a prerequisite, given the risk managers corresponding risk management authority, and enable them to enjoy the risk of operating income. At the same time, the system is use to ensure that the operator is able to assume risk responsibility, bear the risk of loss and come up with the full realization of the responsibility, authority, benefit which is really useful to mobilize the enthusiasm of its risk management and then improve the prevention of enterprise financial risk.

\subsection{Proper Use of Technologies to Prevent Risks}

Methods of financial risk management is refers to the enterprise is going to avoid or reduce the risk, doing financial risk prediction, making decision, prevention and treatment the whole process of continuous management as for the methods and tools to complete the tasks of financial risk management. Some common financial risk prevention methods include:

1) Avoiding financial risks: People can predict the likelihood of occurrence condition of financial risk. They can analysis and judge the risks and the degree of influence on the degree of risk. However it is difficult to grasp the financial activities to be avoided. In general, the risk of long-term investment is greater than the short-term investment risk, investment risk is greater than the debt investment risk. So the choice of investment mode, should adopt the scientific investment decision model. under the premise of ensuring the objectives of financial management, just do some comprehensive evaluation of various options. The management should adhere to the principle, carefully select of investment funds, make more reasonable decisions, pay attention to all kinds of risk investment proportion to avoid excessive dispersion and excessive concentration. At the same time, in the process of implementing plan, if it is found that the unfavorable situation, they can do timely adjustment or suspension of the implementation of the program in order to achieve the purpose of avoiding financial risks.

2) Diversifying financial risk: The method to spread the risk mainly refers to economic unities to take more business, multi investment, multi-party financing, foreign exchange assets of multi-source, to attract many suppliers, for multi-client in order to spread the risks. That can use for continuous training and enhancing their core competitiveness. They can do some appropriate introductions of product diversification, serialization enable best-selling products and unsalable products, product peak season and off-season products, high risk and low risk projects in time, volume and revenue on complement or offset, a loss can is compensated by the return of the other products.

3) Transferring financial risk: Based on the principle of lawful, logical, fair and impartial, we can take measures to transfer the risk. Financial risk transferring refers to financial risk transfer to other units undertaken by some means, including the transfers with insurance and transfers without insurance. Transfers with insurance refer to the enterprise buy a premium from the insurance company regularly in advance. When the loss happens, the insured enterprises can obtain certain economic compensation from the insurance company. Thus the risk tied up by the insurance company will improve the financial stability of the enterprise. Transfers without insurance are to transfer cer- 
tain risks to the specialized agencies or departments. There are usually two ways: one is by contract law. In the financial activities of enterprises, through the signing of the contract, the contract clearly the rights and obligations of both parties in a certain period of time when facing a certain financial accounting risk. The second is by subcontracting method. Some of the great financial risk in the financial activities will be dealt with by some professional agencies or departments.

\subsection{Maintain a Proper Debt Scale and a Reasonable Debt Maturity Structure}

In order to enhance ability to resist financial risks, manufacturing listed companies must control the reasonable debt scale and the structure. The scale of the company's liabilities should be coordinated with repayment ability. What the scale of debt company? There is no definite conclusion. But generally, they need to insure a part of the owners' equity used to be a source of debt repayment. Therefore, borrowing should commensurate with the rights and interests of the owners of the company, generally should not exceed the amount of the net assets. Corporate debt scale is determined generally to the following factors:

1) The proportion of fixed assets: for those companies who have high level of fixed assets. They also have low level of liquidity. So they should control the size of its liabilities in order to insure the money using for repaying.

2) The company's profitability: once the company's profitability is stronger, then their efficiency will be higher. So the debt can bring better benefits and the repayment is generally guaranteed. And then the proportion of liabilities can be appropriately expanded.

3) Company capital turnover rate: once the company production cycle is short, sales to achieve is fast. Then the capital turnover is rapid. It's easy to organize the repayment of funds. On the contrary, the company is prone to delay its paying of debt. At that time, the management should reduce the proportion of liabilities relatively. In a word, company's cash flow level determine the scale of its debt.

The management also needs to consider whether the debt structure is reasonable. The debt structure mainly refers to the proportion of different length of the debts. In general, for long-term debt, there are higher capital cost; for short-term debt, the borrowing cost of capital is lower. To control the cost of capital, enterprise tends to raise the proportion of short-term borrowing. This method can reduce the total cost of funds; however, if the proportion of short-term borrowing is too large, and the risk of default will be very high as well. In general, the needs of short-term temporary funding should be solved by short-term borrowing; long-term funding needs, without issuing stocks, can be settled by long-term borrowing. In terms of short-term borrowing, the company often fall into new loans the old dilemma. That is once they are unable to borrow, they will face the financial risk. In this case there may be causing higher borrowing rates, and reduce the cost of capital. The company has the original intention to draw further details of plans for liabilities. They should make reasonable arrangements for long term or short term borrowing ratios, which is need to prevent over-concen- 
trated repayment period. At the same time, they make a detailed plan for repayment and conduct a necessary repayment funds provision, which is a repayment guarantee. In short, the enterprise must strengthen the ability of decision-making of the management, such as accelerating capital turnover rate, reducing the amount of funds used, trying to shorten the production cycle, raising the sales rate and reducing the accounts receivable to prevent financial risk.

\subsection{Establish Financial Risk Early Warning Mechanism, Strengthen the Financial Crisis Management}

The outbreak of the financial crisis of listed companies is a process of gradual accumulation. It is the result from quantitative change to qualitative change. Because in the process of formation and the outbreak of the financial crisis, there are always challenges that can be grasped and turned into the opportunities. Therefore, the enterprise should establish a real-time, comprehensive, dynamic financial early warning system, which can carry on the real-time monitoring to the company operation and management of potential risks. Once there is financial risk, it sent timely warning message, so that the managers can take effective measures to avoid and reduce losses. The establishment and operation of the financial early warning system should be to the financial statements of the enterprise, business plan and other relevant financial data as the basis, comprehensive investigation to reflect the company's financial position, including the size of the company's assets, liquidity, profitability, financial structure, solvency, asset utilization efficiency and other related indicators. By using scientific financial early-warning mod$\mathrm{el}$, the mechanism is used by the financial management to monitor financial management implementation as a whole.

\section{Conclusion}

The manufacturing enterprise's financial risk involves many aspects, including enterprises operation and development process. The companies should start from themselves. Then they should establish and improve the internal control system and internal audit. So when the enterprises are facing difficulty to avoid financial risk, the management will also take timely measures to control the situation. Therefore, a good internal control system and the financial early-warning system are really in need. At the same time, effectiveness of internal audit is also a strong backing for the operation and development of enterprises.

Because the author's ability is limited, and the research time is short, so the research of this paper has a lot of problems. This paper only focuses on the listed manufacturing enterprises in China. There are some financial risk problems such as corporate finance risk generation causes; financial risk prevention methods can be further studied.

\section{Acknowledgements}

I acknowledge financial support from the Social Science Planning Project of JiangXi Province (Grant No. 14GL05). 


\section{References}

Knight, F. H. (1921) Risk, Uncertainty and Profit (pp. 682-690). Lowa City: Houghton Mifflin Company.

Kong, Y. Y. (2010). Several Suggestions of Financial Risk Control. Strait Science, 3, 56-58.

Li, J. (2010). The Study of Financial Crisis Early Warning Index. Enterpriser World, 9, 88.

Markowitz, H. (1952). Portfolio Selection. The Journal of Finance, 7, 77-91. https://doi.org/10.1111/j.1540-6261.1952.tb01525.x

Ross, S. A., Westerfield, R. W., \& Jordan, B. D. (1995). Fundamentals of Corporate Finance (pp. 233-260). McGraw-Hill Higher Education, New York.

Willianms, C. A., \& Heins, R. M. (1985). Risk Management and Insurance (pp. 99-125). McGraw-Hill Higher Education, New York.

Zhang, Z. M. (2010). The Study of Causal Factors and Countermeasures of Financial Risks. Modern Commercial and Trade Industry, 11, 49.

Submit or recommend next manuscript to SCIRP and we will provide best service for you:

Accepting pre-submission inquiries through Email, Facebook, LinkedIn, Twitter, etc. A wide selection of journals (inclusive of 9 subjects, more than 200 journals)

Providing 24-hour high-quality service

User-friendly online submission system

Fair and swift peer-review system

Efficient typesetting and proofreading procedure

Display of the result of downloads and visits, as well as the number of cited articles

Maximum dissemination of your research work

Submit your manuscript at: http://papersubmission.scirp.org/

Or contact jfrm@scirp.org 